\title{
Hepatitis C in Canada and the importance of risk-based screening
}

\author{
Ha $\mathrm{S}^{1 *}$, Totten $\mathrm{S}^{1}$, Pogany $\mathrm{L}^{1}, \mathrm{Wu} \mathrm{J}^{1}$, Gale-Rowe $\mathrm{M}^{1}$
}

\begin{abstract}
Chronic hepatitis $\mathrm{C}(\mathrm{CHC})$ remains a public health issue affecting an estimated 220,000 individuals in Canada. In 2011, approximately 44\% of those with CHC were unaware of their infection. Hepatitis $C$ is infectious in origin, and if left untreated, can lead to significant morbidity and mortality in its chronic form, including liver cirrhosis, hepatocellular carcinoma and liver failure. These health outcomes are associated with comorbidities, adding a burden to the Canadian health care system. Recent advancements in the treatment of hepatitis $\mathrm{C}$ have changed the clinical landscape.

In Canada, the prevalence of incident cases is higher in specific population groups. Injection drug use (IDU) currently accounts for the highest proportion of new hepatitis $\mathrm{C}$ virus (HCV) infection. It is unclear to what extent HCV infection through health care or personal services use contributed to current prevalent cases of $\mathrm{CHC}$. The Canadian Task Force on Preventive Health Care (CTFPHC) is currently reviewing the evidence for different approaches to HCV screening and the benefits and harms of screening. Risk-based screening remains critical to detecting hepatitis $C$ as knowing one's status has been linked to the cascade of care and improved population health outcomes. This article intends to highlight risk factors associated with the acquisition of $\mathrm{HCV}$ so that health care providers can screen, where appropriate, and detect $\mathrm{CHC}$.
\end{abstract}

\begin{abstract}
Affiliations
${ }^{1}$ Centre for Communicable Diseases and Infection Control, Public Health Agency of Canada, Ottawa, ON
\end{abstract}

\author{
*Correspondence: shalane.ha@ \\ phac-aspc.gc.ca
}

Suggested citation: Ha S, Totten S, Pogany L, Wu J, Gale-Rowe M. Hepatitis C in Canada and the importance of risk-based screening. Can Comm Dis Rep 2016;42:57-62. https://doi.org/10.14745/ccdr.v42i03a02

\section{Introduction}

Hepatitis C, an inflammation of the liver caused by the hepatitis $\mathrm{C}$ virus ( $\mathrm{HCV}$ ), is infectious in origin and can lead to chronic disease with the added dimension of transmission. Hepatitis $C$ is often asymptomatic for decades until liver damage is already underway, highlighting the importance of early detection.

The primary route of transmission is through blood-to-blood contact with an infected individual or product. HCV can cause acute and chronic hepatitis $\mathrm{C}(\mathrm{CHC})$. Approximately $25 \%$ of individuals with acute hepatitis $\mathrm{C}$ will spontaneously clear the virus (1); the remaining $75 \%$ develop $\mathrm{CHC}$, which may progress to cirrhosis, liver failure or hepatocellular carcinoma (2).

Of the seven HCV genotypes known worldwide (3), genotype 1 is the most common in Canada (4) and, until recently, has been difficult to treat. Approvals of new pharmaceuticals for the management of $\mathrm{CHC}$ in Canada have the potential to make $\mathrm{CHC}$ a curable infectious disease.

In Canada, 346 deaths were attributed to $\mathrm{CHC}$ in 2011 (5); however, the number of hepatitis C-related deaths is likely considerably underestimated due to misclassification on death certificates (6). Data from the Canadian Organ Replacement Registry indicate that $21 \%$ of patients who received liver transplants from 2004 to 2013 in Canada had a primary diagnosis of HCV (7). In a 2010 Ontario study, HCV was ranked as one of the most burdensome infectious pathogens in terms of years of life lost due to premature mortality, year-equivalents of reduced functioning, and health-adjusted life years (8), underscoring the impact of this infection on the health of Canadians.

In 2012 and 2013, the Centers for Disease Control and Prevention (CDC) and the U.S. Preventive Services Task Force (USPSTF) released updated guidelines on HCV screening, recommending that all adults born between 1945 and 1965 (also known as "baby boomers") should receive baseline screening for HCV regardless of their risk factors $(9,10)$. The US recommendations to undertake one-time testing of baby boomers were based on epidemiological data demonstrating 1) a high prevalence of HCV in the baby boomer birth cohort; 2) a high proportion of patients with undiagnosed infection; 3) a projected increase in the burden of disease; and 4) indirect evidence linking screening with improved health outcomes $(9,10)$.

Following the release of the US recommendations, the Public Health Agency of Canada examined the projected burden related to hepatitis $C(11)$ and modelled prevalence estimates for anti-HCV and CHC (12). Given the uncertainty around the estimates and the benefits and harms of screening, further analysis was required to determine whether changes should be made to Canada's current risk-based screening 
recommendations. These areas will be addressed by the Canadian Task Force on Preventive Health Care (CTFPHC). CTFPHC is conducting a review of Canadian data to determine the applicability of different screening approaches, including birth cohort screening, in Canada.

The objectives of this article are to highlight the risk factors that contribute to transmitting and acquiring $\mathrm{HCV}$ and to encourage health care providers to assess the need for HCV screening as part of routine medical care while we wait for the results of the assessment of the evidence for birth cohort screening in Canada.

\section{Pharmaceutical management}

The goal of hepatitis $C$ therapy is to achieve a sustained virological response (SVR), defined as having an undetectable viral load in the blood following treatment. Until recently, treatment for hepatitis $C$ consisted of injections of pegylated interferon-alfa and ribavirin, which resulted in $<60 \%$ SVR (13). In addition, the therapies lasted a long time (up to 48 weeks), involved injections and had significant adverse effects (e.g. anemia, fever), which limited the efficacy and tolerability among patients $(13,14)$.

In December 2014, Health Canada approved new short-course interferon-free treatments (15). Genotype 1 patients treated with these new regimens can achieve a SVR of $>90 \%$, with fewer side effects $(14,16,17)$. These new treatments present an opportunity to reduce the morbidity and mortality associated with hepatitis $\mathrm{C}$ and the burden on the health care system. The introduction of the new therapies has shifted the focus from living well with hepatitis $C$ to potentially curing hepatitis $C$.

\section{Epidemiology}

In Canada, HCV has been a notifiable infection under national surveillance since 1991. Provincial and territorial health authorities report cases of HCV infection to the Canadian Notifiable Disease Surveillance System (CNDSS). The latest surveillance data indicate that between 2005 and 2012 the rate of reported cases of HCV decreased steadily from 40.4 per 100,000 to 29.3 per 100,000 population. Rates declined among both males and females in all age groups, with the exception of small increases in males aged 60 years and older and females aged 25 to 29 years. Over the eight-year time frame, rates of reported cases of $\mathrm{HCV}$ were consistently higher in males than in females (18). Although information on acute or $\mathrm{CHC}$ status was not available from most provinces and territories, $\mathrm{CHC}$ infection probably makes up the majority of cases reported to the CNDSS, as acute infection is usually asymptomatic and less likely to be diagnosed (18).

An analysis of cohort effects among cases of HCV reported between 1991 and 2010 in Canada found that those born between 1946 and 1965 contributed more than half of all cases (19). While the rate of reported cases in Canada appears to be decreasing, the number of individuals infected decades ago and now developing sequelae is expected to increase as their disease progresses (20).
Population-based studies of the prevalence of HCV infection provide additional information on the extent of this disease. The Canadian Health Measures Survey (CHMS) found the seroprevalence of HCV antibody (anti-HCV), a marker of lifetime exposure to the virus, to be $0.5 \%$ of the household-dwelling population in Canada over a period of data collection spanning 2007 to 2011 (21). However, modelled prevalence estimates, taking into account vulnerable populations not surveyed by the CHMS, such as the homeless, prison inmates and foreign-born populations who do not speak English or French, indicate that the rate of anti-HCV in the Canadian population may be closer to $1 \%$ (plausibility range, $0.6 \%-1.3 \%$ ) (12). The prevalence of $\mathrm{CHC}$ was estimated to be $0.6 \%$, with approximately $44 \%$ of those being unaware of their infection (12).

\section{Risk factors}

Risk factor information available through national surveillance of $\mathrm{HCV}$ is limited; however, there is a considerable research on the conditions that influence the likelihood of becoming infected with the virus. An overview of practices that increase the risk of acquiring $\mathrm{HCV}$, as well as populations that have been reported to have higher than average rates of $\mathrm{HCV}$ infection, is presented below.

\section{Injection drug use}

Injection drug use (IDU) continues to be the primary cause for incident cases of HCV in developed countries (19). In Canada, among newly acquired $\mathrm{HCV}$ cases with known risk factor information, $61 \%$ had reported a history of IDU (22). In addition, a 2010-2012 survey of people who injected drugs found that $68 \%$ of those surveyed had evidence of exposure to HCV in their lifetime (23). The high prevalence of HCV infection among injection drug users coupled with the high infectivity of HCV make preventing HCV transmission challenging $(24,25)$. IDU or sharing needles or other drug use equipment (i.e. filters, syringes, pipes, spoons), even once, increases the risk of acquiring or transmitting hepatitis $\mathrm{C}$.

\section{Contaminated medical, dental or personal services equipment}

Lack of implementation of standard infection prevention and control practices in health care (e.g. in hospitals, dental offices) or personal service (e.g. tattoo parlours and nail salons) is another risk for HCV infection (26-30). For instance, patients undergoing hemodialysis are at increased risk of acquiring HCV, especially if the equipment has been reused or improperly sterilized (26). In addition, a recent systematic review of international publications reported that health care workers in direct contact with patients or blood (from needle stick injuries) are 1.6 times more likely to be infected with HCV than the general population. Increased prevalence of HCV was found among medical staff (OR 2.2), laboratory staff (OR 2.2) and dental staff (OR 3.5) compared to controls (27). HCV outbreaks have also occurred in colonoscopy clinics in Canada (31-35).

Unsafe tattooing practices using non-sterile equipment increase the risk of acquiring HCV (28). Results from a systematic review 
indicate that risk of HCV increases with increase in the surface area covered by tattoos as well as the number of tattoos (28).

The key to reducing the risk of transmitting infectious diseases in health care and personal service settings is to ensure appropriate education and, training of personnel to be compliant with infection prevention and control practices $(29,30)$.

\section{Blood, blood products and organ transplantation before 1992}

Prior to implementing routine screening of donated blood, blood products and organs in 1992, transfusion and transplantation procedures represented a significant risk for HCV transmission. These risks have been minimized in Canada through routine screening and disposal of donations that contain a transmissible disease; however, this is not the case for all countries. Canadian Blood Services data from 2014 indicate that HCV was detected in 6.1 per 100,000 donations; the residual risk of becoming infected with HCV through receipt of a unit of blood is estimated to be very low at 1 in 6.7 million donations (36).

\section{Vertical transmission}

Mother-to-child or vertical transmission of HCV may occur when an infant is born to a woman with HCV infection. Results from a recent meta-analysis suggest that the risk of vertical transmission from anti-HCV positive and RNA-positive women is about $5.8 \%$ (95\% Cl, 4.2\%-7.8\%), and the risk to children born to an anti-HCV positive mother with spontaneous clearance of infection (RNA negative) was insignificant $(37,38)$.

\section{Other activities that may result in contact with contaminated blood}

Sharing personal care items such as razors, toothbrushes or nail clippers with someone who is HCV-positive is a risk, of a less common one, for acquiring hepatitis $\mathrm{C}$ because $\mathrm{HCV}$ can remain infectious on inanimate surfaces for up to 6 weeks (24).

Though risk for sexual transmission of $\mathrm{HCV}$ during intercourse is low (39), engaging in risky sexual behaviour, such as anal sex without a condom, could result in HCV transmission (40-42) if the mucosa breaks, leading to blood-to-blood contact.

\section{Populations with a higher prevalence of HCV infection}

\section{Men who have sex with men}

Some studies have demonstrated higher rates of HCV infection among HIV-positive men who have sex with men (MSM) compared to HIV-negative MSM $(43,44)$. Some HIV-positive MSM may be more likely to engage in practices that increase the risk of HCV transmission. These practices may include high-risk sexual behaviour (e.g. unprotected anal intercourse or fisting, which may lead to bleeding); IDU and the use of recreational drugs that have been linked to high-risk sexual activity; and serosorting (i.e. choosing sexual partners with the same HIV status as one's own), which has also been linked to transmission of sexually transmitted and bloodborne infections among HIV-positive MSM. In addition, the HIV infection itself, as well as co-infection with other sexually transmitted infections (e.g. syphilis, gonorrhea or chlamydia), may increase susceptibility to HCV through ulceration of genital mucosa or suppression of the immune system (41-43,45-47).

\section{Incarcerated populations}

High rates of HCV infection have been found among inmates of federal and provincial penitentiaries through routinely offered screening. Although not all inmates accept HCV screening, those identified with $\mathrm{CHC}$ are offered treatment depending on their stage in liver fibrosis (48). Recent surveillance data from Correctional Services Canada indicate that $86.1 \%$ of federal penitentiary inmates accepted HCV screening on admission and $18.5 \%$ were positive for HCV in 2012 (49). Risk factors for $\mathrm{HCV}$ acquisition among inmates include contact with infected blood through fights, sexual exposure, IDU or unsafe tattooing practices (50 and unpublished data Correctional Services Canada 2015)

\section{Aboriginal Peoples}

Aboriginal Peoples appear to be disproportionately affected by HCV infection: a pilot survey of Aboriginal people in Regina, Saskatchewan, conducted from 2011-2012 found that $42 \%$ of participants had evidence of exposure to HCV in their lifetime (51-53). As with non-Aboriginal Canadians, IDU is the primary risk factor; additional social determinants that may make Aboriginal people vulnerable to HCV infection include poverty, inadequate housing and lack of access to health care services (51).

\section{Immigrants from countries with high HCV prevalence}

Certain countries have a higher-than-average prevalence of HCV (greater than 3\%); people who were born or resided for a significant period of time in such regions may be at increased risk of HCV infection, particularly in those regions where infection prevention and control measures in health care or personal service settings are not routinely implemented (54). Regions where hepatitis $C$ is more common include Central, East and South Asia; Australasia and Oceania; Eastern Europe; Sub-Saharan Africa; and North Africa/Middle East $(4,55)$.

\section{Screening}

Screening is a viable public health intervention when the following criteria are met: the condition being screened for should be an important health problem; the natural history should be well understood; there should be a detectable early stage; a suitable test should be available for the early stages; treatment at an early stage should be more beneficial than at a later stage; the availability of a diagnostic test should be accepted; intervals for repeat testing should be determined; adequate health service provisions should be available; the benefits should outweigh the harms; effective treatment should be available and accessible; and lastly, the cost should be balanced against the benefits (56).

Screening for $\mathrm{CHC}$ may provide both public health and personal health benefits by interrupting viral transmission (public benefit) and reducing morbidity and mortality (personal benefit).

Achieving SVR is associated with a reduced risk of hepatic events and with patients living healthier lives (57). In addition, early 
diagnosis enables counselling to reduce alcohol consumption, which can slow the progression of liver disease (58).

The public health benefit of identifying undiagnosed cases through risk-based screening is to prevent the acquisition and transmission of HCV in incident cases. A case is being made for birth cohort screening identifying individuals with $\mathrm{CHC}$ who might otherwise remain undiagnosed. The CTFPHC's assessment will shed light on the applicability of birth cohort screening in Canada. Health care practitioners are encouraged to assess the need for HCV screening as part of routine care.

\section{Risk-based screening for hepatitis C}

Current screening recommendations for hepatitis $\mathrm{C}$ in Canada are based on the assessment of risk factors (59). Risks associated with the acquisition of HCV include activities that involve any risk of exposure to contaminated blood or products including:

- IDU or sharing contaminated drug equipment, even once

- Receipt of health care or personal services, where there is a lack of infection prevention and control practices

- Receipt of a blood transfusion, blood products or organ transplant before 1992 in Canada

- $\quad$ Birth or residence in a region where hepatitis $C$ is more common (prevalence $>3 \%$ ), including Central, East and South Asia; Australasia and Oceania; Eastern Europe; Sub-Saharan Africa; and North Africa/Middle East

- Other Risks:

- Sharing personal care items with someone who is HCV-positive

- Participating in risky sexual activity

o Being born to a mother who is HCV-positive

\section{Conclusion}

Hepatitis $C$ is a complex disease in that it is infectious, can remain asymptomatic for decades, can present as a chronic illness and is associated with other chronic comorbidities. The presence of comorbidities may have implications for the diagnosis, management and treatment success of $\mathrm{CHC}$. With the availability of new effective treatment for hepatitis $C$, screening for hepatitis $C$ is important for early detection and to improve population health and patient outcomes. Familiarity with the risk factors for the acquisition of HCV and identifying individuals who are at risk are important to reduce the morbidity and mortality related to hepatitis $\mathrm{C}$ and prevent onwards transmission.

\section{Conflict of interest}

None.

\section{References}

1. Micallef JM, Kaldor JM, Dore GJ. Spontaneous viral clearance following acute hepatitis $C$ infection: a systematic review of longitudinal studies. J Viral Hepat. 2006;13(1):3441.

2. Chen $\mathrm{SL}$, Morgan TR. The natural history of hepatitis $\mathrm{C}$ virus (HCV) infection. Int J Med Sci. 2006;3(2):47-52.

3. Smith DB, Bukh J, Kuiken C, Muerhoff AS, Rice CM, Stapleton JT, et al. Expanded classification of hepatitis $C$ virus into 7 genotypes and 67 subtypes: updated criteria and genotype assignment web resource. Hepatology. 2014;59(1):318-27.

4. Messina JP, Humphreys I, Flaxman A, Brown A, Cooke GS, Pybus $O G$, et al. Global distribution and prevalence of hepatitis C virus genotypes. Hepatology. 2015;61(1):77-87.

5. Statistics Canada. Table 102-0521. Deaths, by cause, Chapter I: Certain infectious and parasitic diseases (A00 to B99), age group and sex, Canada. Ottawa (ON): Statistics Canada; 2014 .http://www5.statcan.gc.ca/cansim/a26?lang= eng\&retrLang=eng\&id=1020521\&pattern=death\&tabMode =dataTable\&srchLan=-1\&p1=1\&p2=-1.

6. Mahajan R, Xing J, Liu SJ, Ly KN, Moorman AC, Rupp L, et al. Mortality among persons in care with hepatitis $C$ virus infection: the Chronic Hepatitis Cohort Study (CHeCS), 2006-2010. Clin Infect Dis. 2014;58(8):1055-61.

7. Webster G, Wu J, Williams B, Ivis F, de Sa E, Hall N. Canadian organ replacement register annual report: treatment of end-stage organ failure in Canada, 2003 to 2012. Ottawa (ON): Canadian Institute for Health Information; 2015. https://secure.cihi.ca/free products/2014_CORR_Annual_Report_EN.pdf

8. Kwong JC, Crowcroft NS, Campitelli MA, Ratnasingham S, Daneman N, Deeks SL, et al. Ontario Burden of Infectious Disease Study (ONBOIDS): an OAHPP/ICES report. Toronto (ON): ICES; 2010. https://www.publichealthontario.ca/en/ eRepository/ONBoID_ICES_Report_ma18.pdf.

9. Smith $B D$, Morgan RL, Beckett GA, Falck-Ytter Y, Holtzman $D$, Teo CG, et al. Recommendations for the identification of chronic hepatitis $C$ virus infection among persons born during 1945-1965. MMWR Recomm Rep. 2012;61:1-32.

10. Moyer VA; U.S. Preventive Services Task Force. Screening for hepatitis C virus infection in adults. Ann Intern Med. 2013; 159(5):349-57.

11. Schanzer DL, Paquette D, Lix LM. Historical trends and projected hospital admissions for chronic hepatitis $C$ infection in Canada: a birth cohort analysis. CMAJ Open. 2014;2(3):E139-44.

12. Trubnikov M, Yan $P$, Archibald $C$. Estimated prevalence of hepatitis $C$ virus (HCV) infection in Canada, 2011. Can Commun Dis Rep. 2014:40;19. http://www.phac-aspc.gc.ca/ publicat/ccdr-rmtc/14vol40/dr-rm40-19/surveillance-b-eng. php. 
13. Manns MP, McHutchison JG, Gordon SC, Rustgi VK, Shiffman M, Reindollar R, et al. Peginterferon alfa-2b plus ribavirin compared with interferon alfa- $2 b$ plus ribavirin for initial treatment of chronic hepatitis C: a randomised trial. Lancet. 2001;358(9286):958-65.

14. Kohli A, Shaffer A, Sherman A, Kottilil S. Treatment of hepatitis C: a systematic review. JAMA. 2014;312(6):631-40.

15. Health Canada. Drug and health products. HARVONI. Summary basis of decision (SBD). Ottawa (ON): Health Canada. http://www.hc-sc.gc.ca/dhp-mps/prodpharma/sbdsmd/drug-med/sbd_smd_2015_harvoni_173180-eng.php.

16. Kowdley KV, Gordon SC, Reddy KR, Rossaro L, Bernstein DE, Lawitz E, et al. Ledipasvir and sofosbuvir for 8 or 12 weeks for chronic HCV without cirrhosis. N Engl J Med. 2014;370(20):1879-88.

17. Poordad F, Hezode C, Trinh R, Kowdley KV, Zeuzem S, Agarwal K, et al. ABT-450/r-ombitasvir and dasabuvir with ribavirin for hepatitis $\mathrm{C}$ with cirrhosis. $\mathrm{N}$ Engl J Med. 2014;370(21):1973-82.

18. Centre for Communicable Diseases and Infection Control. Report on Hepatitis B and C in Canada: 2012. Ottawa (ON): Public Health Agency of Canada; 2012.

19. Trubnikov M, Yan P, Njihia J, Archibald C. Identifying and describing a cohort effect in the national database of reported cases of hepatitis $C$ virus infection in Canada (1991-2010): an age-period-cohort analysis. CMAJ Open. 2014;2(4):E281-7.

20. Remis RS. Modelling the incidence and prevalence of hepatitis $C$ infection and its sequelae in Canada, 2007. Final report. Ottawa (ON): Public Health Agency of Canada; 2007. http://www.phac-aspc.gc.ca/sti-its-surv-epi/model/pdf/ model07-eng.pdf

21. Rotermann M, Langlois K, Andonov A, Trubnikov M. Seroprevalence of hepatitis $B$ and $C$ virus infections: results from the 2007 to 2009 and 2009 to 2011 Canadian Health Measures Survey. Health Rep. 2013;24(11):1-13.

22. Public Health Agency of Canada. Epidemiology of acute hepatitis $C$ infection in Canada: results from the Enhanced Hepatitis Strain Surveillance System (EHSSS). Ottawa (ON): Public Health Agency of Canada; 2009 . http:// publications.gc.ca/site/eng/349885/publication.html

23. Public Health Agency of Canada. Summary of key findings from I-Track Phase 3 (2010-2012). Ottawa (ON): The Agency; 2014. http://www.phac-aspc.gc.ca/aids-sida/publication/ reports/i-track-phase-3/assets/pdf/i-track-phase-3-eng.pdf

24. Paintsil E, Binka M, Patel A, Lindenbach BD, Heimer R. Hepatitis $C$ virus maintains infectivity for weeks after drying on inanimate surfaces at room temperature: Implications for risks of transmission. J Infect Dis 2014;209(8):1205-11.

25. Page K, Morris MD, Hahn JA, Maher L, Prins M. Injection drug use and hepatitis $C$ virus in young adult injectors: using evidence to inform comprehensive prevention. Clin Infect Dis. 2013;57(S2):S32-8.

26. Su Y, Norris JL, Zang C, Peng Z, Wang N. Incidence of hepatitis $C$ virus infection in patients on hemodialysis: a systematic review and meta-analysis. Hemodial Int. 2013;17(4):532-41.
27. Westermann C, Peters C, Lisiak B, Lamberti M, Nienhaus A. The prevalence of hepatitis $C$ among healthcare workers: a systematic review and meta-analysis. Occup Environ Med. 2015;72(12):880-8.

28. Jafari S, Copes R, Baharlou S, Etminan M, Buxton J. Tattooing and the risk of transmission of hepatitis $C:$ a systematic review and meta-analysis. Int J Infect Dis. 2010;14(11):e928-40.

29. Bianco A, Bova F, Nobile CG, Pileggi C, Pavia M, Collaborative Working Group. Healthcare workers and prevention of hepatitis $C$ virus transmission: exploring knowledge, attitudes and evidence-based practices in hemodialysis units in Italy. BMC Infect Dis. 2013;13(76).

30. Yang J, Hall K, Nuriddin A, Woolard D. Risk for hepatitis B and $C$ virus transmission in nail salons and barbershops and state regulatory requirements to prevent such transmission in the United States. J Public Health Manag Pract. 2014;20(6):E20-30.

31. CBC News. Hepatitis $C$ outbreak identified at Kitchener colonoscopy clinic. 2015 Feb 03; Kitchener-Waterloo. http://www.cbc.ca/news/canada/kitchener-waterloo/ hepatitis-c-outbreak-identified-at-kitchener-colonoscopyclinic-1.294360332.

32. Region of Waterloo. Public Health and Emergency Services. Hepatitis C - Tri-City Colonoscopy Clinic Investigation. 2015 Feb 3. http://chd.region.waterloo.on.ca/en/ healthyLivingHealthProtection/resources/PHE_IDS_15_02_ HEPC.pdf.

33. Toronto Metro. Experts warn against use of multi-dose vials after hepatitis C outbreak at Toronto clinics. 2014 Sep 30; News/Canada. http://www.metronews.ca/news/ canada/2014/09/30/experts-warn-against-use-of-multi-dosevials-after-hepatitis-c-outbreak-at-toronto-clinics.html.

34. Boyle T. Hepatitis C outbreaks at three Toronto colonoscopy clinics kept secret. The Toronto Star. 2014 Sep 27; Life/ Health \& Wellness. http://www.thestar.com/life/health_ wellness/2014/09/27/hepatitis_c_outbreaks_at_three_ toronto_colonoscopy_clinics_kept_secret.html.

35. Ruby M. Test confirms patient infected with hepatitis C during May 29, 2013, procedure at BGH. Brantford Expositor. 2014 Jan 29; News Brantford-Brant http://www. brantfordexpositor.ca/2014/01/29/test-confirms-patientinfected-with-hepatitis-c-during-may-29-2013-procedure-atbgh.

36. Canadian Blood Services: surveillance report, 2014. Ottawa (ON): Canadian Blood Services; 2014. https://www.blood.ca/ sites/default/files/blood/blood-safety/External-SurveillanceReport-2014.pdf.

37. Benova L, Mohamoud YA, Calvert C, Abu-Raddad LJ. Vertical transmission of hepatitis $C$ virus: systematic review and meta-analysis. Clin Infect Dis. 2014;59(6):765-73.

38. Robinson JL; Canadian Pediatric Society. Vertical transmission of hepatitis $C$ virus: current knowledge and issues. Ottawa (ON): Canadian Pediatric Society; 2014. http://www.cps.ca/en/documents/position/verticaltransmission-of-hepatitis-C. 
39. Terrault NA, Dodge JL, Murphy EL, Tavis JE, Kiss A, Levin $T R$, et al. Sexual transmission of hepatitis $C$ virus among monogamous heterosexual couples: the HCV partners study. Hepatology. 2013;57(3):881-9.

40. Witt MD, Seaberg EC, Darilay A, Young S, Badri S, Rinaldo $C R$, et al. Incident hepatitis $C$ virus infection in men who have sex with men: a prospective cohort analysis, 1984-2011. Clin Infect Dis. 2013;57(1):77-84.

41. Wong J, Moore D, Kanters S, Buxton J, Robert W, Gustafson $R$, et al. Seroprevalence of hepatitis $C$ and correlates of seropositivity among men who have sex with men in Vancouver, Canada: a cross-sectional survey. Sex Transm Infect 2015;91(6):430-3.

42. Foster AL, Gaisa M, Hijdra RM, Fierer DS, Jacobson K, Turner $\mathrm{S}$, et al. Rectal shedding of HCV in HCV/HIV co-infected men.; San Francisco (CA): AASLD Liver Meeting 2015; 2015 Nov 13-17. Abstract 89.

43. Burchell AN, Gardner SL, Mazzulli T, Manno M, Raboud J, Allen VG, et al. Hepatitis C virus seroconversion among HIV-positive men who have sex with men with no history of injection drug use: Results from a clinical HIV cohort. Can J Infect Dis Med Microbiol. 2015;26(1):17-22.

44. Yaphe S, Bozinoff N, Kyle R, Shivkumar S, Pai NP, Klein M. Incidence of acute hepatitis $C$ virus infection among men who have sex with men with and without HIV infection: a systematic review. Sex Transm Infect. 2012;88(7):558-64.

45. Apers L, Vanden Berghe W, De Wit S, Kabeya K, Callens S, Buyze J, et al. Risk factors for HCV acquisition among HIV-positive MSM in Belgium. J Acquir Immune Defic Syndr. 2015;68(5):585-93.

46. Breskin A, Drobnik A, Pathela P, Chan C, Braunstein S, Bornschlegel K. Factors associated with hepatitis $C$ infection among HIV-infected men who have sex with men with no reported injection drug use in New York City, 2000-2010. Sex Transm Dis. 2015;42(7):382-6.

47. Reinhart J. Sexual transmission of hepatitis C: are HIVpositive gay and bisexual men at risk? Toronto (ON): CATIE; 2011. http://www.catie.ca/en/pif/spring-2011/sexualtransmission-hepatitis-c-are-hiv-positive-gay-and-bisexualmen-risk\#

48. Zakaria D, Thompson JM, Jarvis A, Smith J. Testing and treatment for human immunodeficiency virus and hepatitis $C$ virus infections among Canadian federal inmates. Ottawa (ON): Correctional Service of Canada; 2010. http://www.cscscc.gc.ca/005/008/092/005008-0223-01-eng.pdf

49. Correctional Services Canada. Bloodborne and sexually transmitted infections in Canadian federal penitentiaries: program overview. In: Ontario HIV/AIDS Trials Network Conference; 2014 Nov 30. Kingston, ON.

50. Wenger PJ, Rottnek F, Parker T, Crippin JS. Assessment of Hepatitis C Risk Factors and Infection Prevalence in a Jail Population. Am J Public Health. 2014 September; 104(9): 1722-1727.

51. Public Health Agency of Canada. Summary of key findings from the A-Track pilot survey (2011-2012). Ottawa (ON): 2013. http://publications.gc.ca/collections/ collection_2014/aspc-phac/HP40-118-2014-eng.pdf.
52. Frescura AM, Fang L, Trubnikov M, Klar S, Jayaraman G. Centre for Communicable Diseases and Infection Control. Hepatitis C in Canada: 2005-2010 surveillance report. Ottawa (ON): Public Health Agency of Canada; 2012. http:// canadiensensante.gc.ca/publications/diseases-conditionsmaladies-affections/hepatitis-b-c-2012-hepatite-b-c/indexfra.php.

53. Spittal PM, Pearce ME, Chavoshi N, Christian WM, Moniruzzaman A, Teegee M, et al. The Cedar Project: high incidence of HCV infections in a longitudinal study of young Aboriginal people who use drugs in two Canadian cities. BMC Public Health. 2012;12:632.

54. Greenway C Ma AT, Kloda LA, Klein MB, Cnossen S. The seroprevalence of hepatitis $C$ in immigrants and refugees from intermediate and high endemic countries: a systematic review and meta-analysis. Gastroenterology. 2015;148(4;S1):S998-9.

55. Smith B, Falck-Ytter Y; Guidelines Development Group. Guidelines for the screening, care and treatment of persons with hepatitis $\mathrm{C}$ infection. Geneva $(\mathrm{CH})$ : World Health Organization; 2014 Apr. http://apps.who.int/iris/ bitstream/10665/111747/1/9789241548755_eng.pdf.

56. Wilson JM, Jungner G. Principles and practice of screening for disease. Geneva (CH): World Health Organization; 1968.

57. Innes HA, McDonald SA, Dillon JF, Allen S, Hayes PC, Goldberg D, et al. Toward a more complete understanding of the association between a hepatitis $C$ sustained viral response and cause-specific outcomes. Hepatology. 2015;62(2):355-64.

58. Zule WA, Costenbader EC, Coomes CM, Wechsberg WM. Effects of a hepatitis $C$ virus educational intervention or a motivational intervention on alcohol use, injection drug use, and sexual risk behaviours among injection drug users. Am J Public Health. 2009;99(S1):S180-6.

59. Public Health Agency of Canada. Primary care management of chronic hepatitis C: professional desk reference 2009. Mississauga (ON): College of Family Physicians of Canada; 2009. Joint publication of the Public Health Agency of Canada. http://www.catie.ca/sites/default/files/Primary-CareManagement-of-Chronic-Hepatitis-C-Professional-DeskReference.pdf. 